\title{
Geometry and Technical Drawing in the Secondary School Journal: Knowledge for Teaching (1957 to 1963)
}

\section{Geometria e Desenho na Revista Escola Secundária: Saberes para o Ensino (1957 a 1963)}

\author{
Maria Cristina Araújo de Oliveira*a; Ruy César Pietropaolo ${ }^{\mathrm{b}}$
}

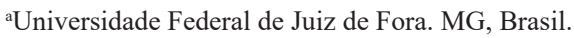

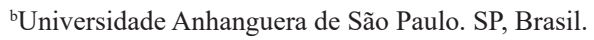

*E-mail: mcrisoliveira6@gmail.com

\begin{abstract}
This study presents an analysis of articles on Mathematics and Technical Drawing, published in the Brazilian Secondary School Journal, between 1957 and 1963, in order to provide a panorama of theoretical and practical recommendations, emphasized and defended in these papers, regarding to teaching and learning processes of notions, concepts and procedures relative to geometry and especially whether the History of Mathematics was used a tool for teaching and learning Mathematics. This journal has been structured as a teacher training esource, as it has emerged in a context in which the large majority of Brazilian secondary school teachers were self-taught because, in 1957, only $16 \%$ of in-service teachers had graduated from Schools of Philosophy. For this analysis, we assume that the pedagogical media, which resulted from editorial strategies aimed at teachers, plays a significant role in the dissemination of ideas and knowledge understood as necessary and fundamental for the teaching practice. In this paper, we identify recommendations on the teaching and learning process for geometry, which are highlighted in the process of teacher professionalization, according to the appropriation perspective (Certeau 1994, Chartier 1991 and Carvalho 2006) of the educational legislation of the 1950s, followed by different authors of the analyzed articles.
\end{abstract}

Keywords: History of Mathematics Education in Brazil. Mathematics Teacher Training in Brazil. Pedagogical Media.

\section{Resumo}

Este estudo apresenta uma análise de artigos sobre Matemática e Desenho, publicados na Revista do Ensino Médio, entre 1957 e 1963, com a finalidade de fornecer um panorama de recomendações teóricas e práticas, enfatizadas e defendidas nesses artigos, no que se refere aos processos de ensino e aprendizagem de noções, conceitos e procedimentos relativos à geometria e, principalmente, se a História da Matemática foi utilizada como ferramenta para ensinar Matemática. Este periódico se estruturou como um recurso para a formação de professores, pois surgiu em um contexto em que a grande maioria dos professores do ensino médio brasileiro eram autodidatas, uma vez que em 1957 apenas $16 \%$ dos professores em serviço eram formados em escolas de Filosofia. Para esta análise, partimos do pressuposto de que os meios pedagógicos, fruto de estratégias editoriais dirigidas aos professores, desempenham um papel significativo na difusão de ideias e saberes entendidos como necessários e fundamentais para a prática docente. Neste artigo, identificamos recomendações sobre o processo de ensino e aprendizagem da geometria, que se destacam no processo de profissionalização docente, segundo a perspectiva de apropriação (Certeau 1994, Chartier 1991 e Carvalho 2006) da legislação educacional dos anos 1950, seguida por diferentes autores dos artigos analisados.

Palavras-chave: História da Educação Matemática no Brasil; Formação de professores de Matemática; Mídia Pedagógica.

\section{Introduction}

This study presents an analysis of articles on Mathematics and Technical Drawing, published in Brazil between 1957 and 1963 , in the Secondary School Journal, in order to provide a panorama of the theoretical and practical recommendations emphasized and defended in these papers, regarding the teaching and learning processes of notions, concepts and procedures relative to these disciplines, and, in particular, whether the history of Mathematics was suggested as a means of teaching and learning Mathematics.

Our goal was to identify professional knowledge from the perspective of professional competencies (Oliveira, 2015) for teaching Mathematics and Technical Drawing. In other words, rationalized knowledge on teaching takes into account the content and respective adaptations to students in each grade: level of education, learning methods, suggested materials, among other aspects. Pedagogical journals participate in the process of teacher professionalization, with the publications (Certeau 1994, Chartier 1991, \& Carvalho 2006) by the different authors of the articles analyzed embodying appropriations on educational legislation, the Brazilian socioeconomic context in the 1950s, proposals and debates in Brazilian Conferences on Teaching Mathematics, which started in 1955 and occurred biannually during that decade.

Following Fernandes, Xavier \& Carvalho (2006, p. 45), we assume that the pedagogical media, which resulted from editorial strategies aimed at the class of teachers, plays a significant role in the dissemination of ideas and knowledge understood as necessary and fundamental for the teaching practice. According to Fernandes et al. (2006), journals and periodicals aimed at teachers are perceived as entities that play an important role in circulating and producing knowledge: theories, models, practices, experiments, among others. 
We believe that the history of a discipline can contribute to an understanding of teaching practices and to proposals for change. According to Valente (2008), considering the historical perspective of the work of mathematics teachers can lead to a broadened or new meaning given to their actions. Therefore, understanding past contexts of teaching Mathematics allows us to identify innovations and constants among the teaching practices of Mathematics teachers.

\section{The Secondary School Journal}

The Campaign for the Improvement and Expansion of Secondary School (CADES, Campanha de Aperfeiçoamento e Difusão do Ensino Secundário), a government action carried out by the Ministry of Education and Culture from 1953 to 1971, had the goals of expanding Secondary Education throughout Brazil and improving teaching quality, considering the highly book-based, abstract and elitist nature that characterized the teaching and learning processes in schools. Therefore, one of the purposes of the Campaign was to broaden and elevate the level of secondary education, "to adapt secondary education to the interests and needs of the time, provide effectiveness and social meaning to teaching, as well as create possibilities for young people to have access to secondary education"1 (Baraldi, 2003, p.146).

One of the actions by CADES, starting in 1956, was to offer intensive preparatory courses for exams that granted to those approved a teaching certificate for secondary education and the right to teach where those with teaching degrees from Schools of Philosophy were not available. This action was justified by the fact that in the 1950s there was a major expansion in the network secondary schools and, consequently, an increase in enrollment numbers, while the number of trained teachers did not grow in the same proportion.

In addition to courses for secondary school teachers, CADES also held conferences for the directors, workshops on educational guidelines, meetings for secondary education inspectors and courses for secretaries of teaching establishments.

Among the range of activities carried out by CADES is the publication of the Secondary School Journal (from 1957 to 1963), the purpose of which was to guide teachers in curricular, legal and didactic aspects. In the first edition of the Journal, the first article presents the panorama of Brazilian secondary education at the time and claims that the intention behind creating the journal was "to serve as a vehicle for exchange among Brazilian teachers, to exchange ideas, suggestions and experiences, to promote the creation of a new, more progressive mentality, more favorable to objective observation, to renewed experimentation and a critical review of postulates, goals, curricula and methods upon which all of our teaching is based"2 (Secondary School Journal n ${ }^{\circ}$ 1, 1957, p.8).

It is worth pointing out that some sections of this Journal, which was published quarterly, were not only concerned with discussing or consolidating technical knowledge coming from General Teaching, but especially with providing support for preparing more appealing classes, in order to spark student interest with specific themes in a discipline and thus promote a more efficient teaching and learning process. All nineteen editions of the journal addressed topics relative to the various disciplines or areas that composed the curriculum: languages, mathematics, technical drawing, history, geography, physics, chemistry, natural sciences, philosophy, handcrafts, home economics, etc. In other words, the articles published covered teaching techniques and methods, discussing the appropriate use of teaching materials and presenting plans for developing specific topics, in addition to course programs for some of the grades. All editions presented at least one article on Mathematics and one on Technical Drawing.

One of the sections in the Journal, under the title National Education Establishments, was focused on presenting innovative experiences with the goal of demonstrating, through examples, that it was possible to experiment with new pedagogical proposals and it could lead the school and the teacher to getting good results.

Upon analyzing the Secondary School Journal, Fernandes et al. (2006) claim that its purpose was to take to different Brazilian states, especially rural areas, the pedagogical knowledge considered appropriate for developing secondary teaching, as well as to publish the legislation in effect for this level of education, including comments on its pertinence and range.

Also according to Fernandes et al. (2006), the Journal functioned as a vehicle for legitimizing the actions of the Board of Secondary Education in the Ministry of Education and Culture (DESE-MEC), providing information on teacher training programs by MEC, justifying their existence and suggesting that teachers and schools, public as well as private, participate in the Program of Experimental Secondary Classes. Through this Program, the Ministry of Education stimulated experimentation with new proposals and pedagogical models to be tested and evaluated in secondary education.

In sum, we can claim that the journal was structured as a teacher training resource, since CADES emerged in a context in which the large majority of Brazilian teachers in this segment of education were self-taught: in 1957, only $16 \%$

\footnotetext{
1 Original text: tornar a educação secundária mais ajustada aos interesses e necessidades da época, conferindo ao ensino eficácia e sentido social, bem como criar possibilidades para que os mais jovens tivessem acesso à escola secundária.

2 Original text: servir de veículo de intercâmbio entre o professorado brasileiro, na troca de ideias, sugestões e experiências, favorecendo a formação de uma nova mentalidade, mais progressista, mais propícia à observação objetiva, à experimentação renovadora e à revisão crítica dos postulados, finalidades, currículos e métodos em que se baseia toda a atuação de nosso magistério.
} 
of working teachers had teaching degrees from Schools of Philosophy.

\section{Mathematics for Teaching}

In its 19 editions, the Secondary School Journal published 34 papers on Mathematics and its teaching, including articles, reports and teaching plans, all written by renowned teachers of the time. These papers discussed a wide variety of topics: analyses of mathematical content taught in schools and of student performance assessment instruments; teaching arithmetic and geometry; teaching deductive geometry; formal proofs in Mathematics; teaching linear systems; arithmetic and psychology of learning; History of Mathematics; using materials and laboratories as methods for teaching Mathematics; student motivation; Mathematics and Natural Sciences; examples of guided studies in Mathematics; teaching statistics.

After an initial reading of the papers, we observed a broad range of subjects addressed in them and the lack of a project that systematically included, in each number, publications aimed at the two stages of secondary education (junior high and high school), alternating between a focus on one, then on the other. Moreover, there were no criteria for distributing the articles across the different sets of mathematical contents. For example, there are few references to teaching algebra. One can also claim that the suggestions presented aimed to diverge from some of the dominant practices in teaching Mathematics at the time. However, the articles on Mathematics did not take into account the pedagogical aspect of the History of Mathematics in school curricula.

Since it was not possible to analyze all of the articles published by the journal that address Mathematics, we have chosen those that focus on geometry, to highlight the didactic guidelines published in them. We chose to present a summary of these papers, not only because they are greater in number, but mainly due to the concerns that the authors had with teaching this area of Mathematics, which are still very present today: what geometry is and how to teach it, deduction in geometry, the scope of geometric content and the existence of suggestions on the didactic use of the history of these concepts.

It is worth highlighting that all of these papers basically discuss the issue of deductive geometry, leaving very little space, when any is left, to what is called "intuitive geometry", which fundamentally includes terminology and measurements (areas and perimeters).

We also chose two other papers, not exclusively about geometry: one that discusses a Mathematics laboratory and another that criticizes programs and assessments developed in schools. These choices were made due to the richness they add to our analysis: one can identify the authors' appropriation of the legislation, regarding the pedagogical models that they intended to promote.

In our analysis of these papers, we identified the way in which the authors appropriated the principles that the Secondary Journal intended to disseminate, considering that it was conceived as an editorial strategy by the Ministry of Education to intervene in the teaching and learning processes. As such, we are guided by the following question: which professional competencies can be identified for teaching Mathematics and Technical Drawing?

From this perspective, it is worth noting some aspects from the regulation of 1951, which established the minimum programs of the time. According to the Congregation of the Pedro II School ${ }^{3}$, providing minimum programs, as mentioned in the regulation, would define new paths for secondary teaching: "...it is easy to determine that this new guideline, obeying the constitutional precept and provided in the law 'Guidelines and Foundations', will cause a revolution in secondary teaching. The program adopted until then did not allow for any flexibility needed to attend to the specific regional characteristics of our immense territory"4. (Brazil, laws and decrees: letter 305 of September 21 of 1951).

Contrary to the Organic Law of Secondary Education (1942), which did not have didactic guidelines in its programs, the regulation of 1951 presented some methodological recommendations, though they did not constitute anything new, since most of them were in the curricula of the Francisco Campos Reform (1931). The paper regarding Pedagogical Instructions suggests, for example, that education, especially in the first few years of junior high school, should essentially be practical and intuitive in nature: the deductive method in geometry should only be introduced at the end of junior high with the care that it requires and to the extent that the student feels the need for justification, a proof and a formal proof.

In our analysis of the articles that specifically address issues relative to formal proofs in geometry, we observed that the authors intended to follow the legislation, emphasizing, for example, the need to start deductive reasoning with theorems of plane geometry. In fact, we see recommendations for formal proofs to be done only in the $3^{\text {rd }}$ and $4^{\text {th }}$ years of junior high, with the justification that the subject is difficult and tedious.

The author of one of the papers ${ }^{5}$ warns that, in order for teachers to minimize difficulties in the teaching and learning process of geometry, presented fundamentally through

\footnotetext{
3 The Pedro II school, located in the city of Rio de Janeiro, founded in 1837, was a reference for Brazilian secondary education, until the first half of the past century, influencing the creation of legislation and programs to be followed throughout the country.

4 Original text: “.... é fácil verificar que essa nova orientação, obedecendo ao preceito constitucional e antecipando-se à lei de 'Diretrizes e Bases', virá causar uma revolução no ensino secundário. Os programas até então adotados não permitiam a menor flexibilidade que viesse atender às peculiaridades regionais de nosso imenso território".

5 Professor Antonio Domingues.
} 
deduction, they should first organize a list of axioms, including theorems of intuitive formal proof, and then "select a set of fundamental theorems and their main consequences, such that they constitute optimal material for training students in formal proofs" (Secondary School Journal, n.7, p.65). Therefore, in this article, the author considers that deductive geometry in junior high school should be seen more as an initiation in formal proof methods than as a proper development of a theory.

However, when this same author presents a scheme to exemplify the development of deductive geometry in the 3rd year of junior high, there is a proposal of an extensive list of theorems to be proved, emphasizing that some of them should be proved using the notion of movement, perhaps an effort to minimize the complexity of the task and the length of the list. The extensive contents, according to this author, would precisely be one of the main problems of the teaching and learning process of Mathematics.

In a way, this proposal goes against the norms established by the regulation of 1951 , since, according to the latter document, the theorems should be developed gradually, according to student interest. Moreover, this regulation highlights the importance of active student participation in the teaching-learning process and the need to capture their attention and interest. In the 1951 regulation, it was also suggested that one should always be aware that teaching does not depend on the discipline in itself, but mainly, on the student being taught and that what matters is not teaching a lot, but teaching well. This is the first time an official document has declared that classroom actions should take into account that Mathematics is not pure logic and that the focus should be on the student.

Another article 6 , which highlights the importance of formal proofs in adolescent education, claims that not proposing formal proofs in schools may prevent them from achieving the indirect goals of teaching Mathematics: reflection, reasoning, conclusion, deduction, induction, order, etc. The article also highlights that "the formal proof done with active classroom participation educates thinking and forces students to remain attentive in order not to break the logical sequence when called on to participate" (Secondary School Journal, n.3, p.72). However, it does not discuss the possible ways to carry out this work. The author also mentions the issue of expanding Mathematics programs, notably geometry.

In another article ${ }^{8}$ in the Journal, five fundamental points are considered for teaching geometry: accessible and direct language for young people; presentation of initial geometric properties through direct reasoning and empirical proofs; mastery of the subject through very simple problem-solving, bypassing so-called mathematical intuition; preparation for geometric proofs by practicing calculations in schematic form; construction of a logical system of propositions, only after an empirical and illustrative exposure to this first part of geometry.

Reading the articles on Geometry enables us to say that the authors aimed to follow the principles that governed the "Minimum Programs", such as the fact that students should be the center of the teaching process and not only how Mathematics is organized. However, one possible appropriation of the Programs' principles is to adapt the content and methods to different realities; however, according to these authors, this does not happen, at least not explicitly.

Some of the authors of the papers involving geometry also consider, though indirectly, the range of contents and claim that some topics on the list of minimums are indispensable. Others also admit that this list is in fact very extensive. This is corroborated by an analysis by one group of teachers of the subjects on the partial Mathematics exams, in 1958, in various teaching establishments in a secondary program.

Regarding programs developed by these schools, the authors report that the majority did not meet the minimum program, highlighting that some did not even have $1 / 5$ of it. The following passage reveals the concern of inspectorteachers: "We observe that the essential of minimum programs is not implemented: in the study of mathematics, one cannot sacrifice determined subjects without incalculable damage to the students!"'9 (Secondary Journal, v. 10, p. 83). These teachers made recommendations to overcome these difficulties, suggesting, for example: to increase the number of Mathematics classes; that teachers organize, at the beginning of the year, a feasible program plan, to include what is essential for each grade. However, they do not criticize the document that publishes the minimums and appear to fully assume the official discourse, perhaps because it temporarily plays the role of inspector, thus, a position of control.

Regarding how to teach geometry, some papers aim to advance beyond the pedagogical suggestions of the minimum programs (regulation of 1951), suggesting to teachers different methodologies for student learning. However, we can identify contradictions in their discourses.

To this end, we cite the article The Mathematics Laboratory Method by Malba Tahan ${ }^{10}$. This article suggests

6 Authored by Eleonora Lôbo Ribeiro

7 Original text: "a demonstração feita com a participação ativa da classe, educa não só o pensamento, obrigando o aluno a ficar atento para não quebrar a seqüência lógica quando chamado a participar".

8 Written by Thales Mello Carvalho, author of various Mathematics teaching books in the 1950s.

9 Original text: “observa-se a não execução dos programas mínimos no que têm de essencial; no estudo de matemática não é possível sacrificar-se determinados assuntos sem prejuízos incalculáveis para os alunos!"

10 Malba Tahan was the pseudonym used by teacher Júlio César de Mello e Sousa, who was a professor at Pedro II School, a renowned author of didactic books, in the first half of the last century. Signing as Malba Tahan, he became known especially for his book The man who calculated, which was translated into several languages. 
and describes the materials that should be included in the laboratory. Moreover, some activities are suggested, such as: foundation of a mathematics club, publication of a monthly bulletin, conferences, etc. Teacher Tahan also presents in his paper quotes from some personalities who defend the use of concrete materials in teaching Mathematics, such as Rui Barbosa, regarding the importance of "Tachymetry by Lagout" - the only method that enables teaching geometry and proofs of theorems "to the most elementary intelligences" (p.78). Similarly, it presents a defense of Euclides Roxo, a Brazilian emeritus mathematics educator, regarding "the excellencies" of the Laboratory for allowing "self-discovery", which would be a possible way to help students "to climb up the steep ramp of mathematical abstraction"11 (p.79).

Tahan also listed the advantages of the Laboratory for teaching Mathematics, such as: leading the students to making discoveries; learning among less gifted students; motivating students and teachers. However, the author presented the disadvantages of the method: leading the student to accept as rigorous, certain experimental and rough formal proofs; leading the student to move away from abstractions and pursue material resources for formal mathematical proofs; it is very onerous; it requires a lot of time and as a result they may not complete the program; it requires a lot of preparation by the teacher; may not apply to all points in the program.

If one of the roles of the journal was precisely to publish new methodologies, to emphatically point out the disadvantages of a method, especially those that are admittedly concerns for teachers, would this not be a rejection of the innovations that one wished to suggest and try?

It is worth noting that, while Malba Tahan wrote articles on the history of Mathematics, he did not propose using this history as a way to teach concepts of this discipline.

\section{The Multiple Possibilities for Technical Drawing}

In our analysis, we included articles that addressed technical drawing with the goal of determining the extent to which proposals for teaching technical drawing, published in the Secondary School Journal, approached or diverged from Mathematics, more specifically, geometry. The 19 editions of the journal have 21 articles on technical drawing.

The goal of these articles is especially to outline the space of the technical drawing teacher as a professional, with his own identity, as well as the importance of this discipline.

One of the articles that addresses the subject quite explicitly, outlines a model for this professional, teacher of technical drawing, that distinguishes him from artists, engineers, Mathematics teachers, and primary teachers. Over the course of various articles, the characteristics that a technical drawing teacher must have in order to satisfactorily perform their function are discussed, personal requirements that include drawing skills, composing forms and colors, having the dexterity and confidence to handle instruments, having the capacity for abstraction, having an aesthetic sense, among others.

The importance of technical drawing in student education is defended in a dual perspective, cultural, as well as economic, to the extent that "scientific" drawing is useful in crafts, in industry, in constructions, and emphasized as necessary in different professions: military, doctors, tailors, artisans, among others. Another argument used to validate the discipline is the importance of the psychological function that drawing plays in the progressive maturity of the child.

Drawing programs encompass the following aspects: natural, decorative, geometric and projective, which, due to their distinct natures, created difficulties for teacher training, as well as for adopting textbooks aimed at teaching the discipline.

One of the articles addressed the complex path for training drawing teachers, carried out in universities. This paper clarifies the nature of this program, highlighting the broad training in descriptive and projective geometry, and geometric drawing. According to the author's evaluation, the program is based on two distinct areas of knowledge: science and art, in addition to pedagogical knowledge in the last year.

Given the lack of professionals who can teach the two distinct areas of knowledge well, one of the articles proposed a division, in the final years of secondary education, between drawing, which he called technique, corresponding to geometric and projective drawing, and artistic, natural and decorative drawing. The former is aimed at technical careers: engineers, architects, mathematicians, among others. The latter is aimed at non-technical training: doctors, dentists, teachers, etc.

The bibliography for teaching drawing was also problematic, as revealed in one of the published articles, which suggests some books, but highlights the insufficient references in Portuguese, given the scope of the discipline.

The importance of didactics, especially the didactics specific for drawing, is also one of the aspects strongly discussed in different volumes of the journal. Some articles address the question in a more theoretical way, providing teachers with considerations on factors that restrict and condition the teaching action: people's economic situation, the educational system, the educational purposes and goals, among others. Analyzing these aspects in Brazil at that time, one of the authors considered that the country was undergoing a major transformation, the main factor being the growing industrialization, while the rate of illiteracy varied from 50\% to $80 \%$. For this author, teaching played an important and useful role in the progress of the nation. (Santos 1958a, p.9194).

Some articles highlight the care that should be taken with the students. One of the articles defended that the main concern 
of the drawing teacher in secondary school should be with the student. According to the author, the teacher must plan and guide his activities to meet student needs for growth and education "taking into consideration their limitations as well as their individual differences" (Santos 1958a, p.93). This is why it becomes essential to have knowledge of Evolutionary and Differential Psychology for children and adolescents. The conclusion of the article presents a summary of the "evolutionary stages of child drawings". Nevertheless, there are no indications or suggestions for the teacher to consider the differences and limitations of the various student groups.

Addressing didactics from a more practical point of view, some articles describe how classes should be taught, presenting the dual work of explaining the content and how to teach it.

This is the case, for example, of three articles published over three different editions, between 1957 and 1958, in which teacher Wanderley addressed the teaching of descriptive geometry using the method of orthogonal projections. In each of these articles, the author thoroughly describes how the teacher should teach their students to project on orthogonal planes and build the corresponding epura. It presents interesting suggestions for concrete materials that should be used in the classroom, such as supporting resources in the explanations: the use of embedded paperboard to represent the orthogonal planes, paper balls for the points, and sticks for the lines. The author also calls for teachers to determine whether students understood each step of what was taught before proceeding to the explanation. The articles by teacher Wanderley have a dual role of teaching the subject to the teacher and how the teacher should teach it to the students.

Teacher José Sennem Bandeira ${ }^{12}$ writes the article on technical drawing in the first publication, in which he presents a brief history of teaching technical drawing in France and Brazil and their relation of proximity with and divergence from geometry in history. One of the periods of divergence between notions of drawing and geometry were, according to this author, due to the influence of psychologists in defense of free, spontaneous drawing, uncorrupted by "methods of geometric foundation" (Bandeira 1957, p.75). However, the development of psychological studies on the evolutionary steps of spontaneous drawing in children revealed that these stages fatally end in the so-called regression phase, in which a child's critique of his own drawings discourages him from continuing to draw. Teaching drawing using geometry-based methods would lead students to overcoming this stage. As such, the author supports the 1951 regulation of minimum programs, which form the foundation for drawing in Euclidean geometry, thus defending the importance of freehand drawing, without using instruments (ruler, compass, protractor) in the first years of junior high.
The last article on technical drawing published in the Secondary School Journal has a very different tone from the others. While not very didactic, it discusses a topic that, according to the author, was not worked on very much due to it being planned for the end of the junior high program: equivalence of areas. The author criticizes geometric drawing lessons in which the content is taught using "recipes" and evaluates that the lack of student motivation is due to the fact that they were not presented with reasons. In his paper, he justifies the constructions made in the equivalence problems, based on mathematical concepts related to the calculation of areas. The arguments used by the author are based on new ideas that began to circulate in the beginning of the 1960s, among Mathematics teachers, with the so-called Modern Mathematics Movement.

The articles did not reveal that there was a connection between teaching Technical Drawing and Mathematics. On the contrary, there are signs of divergence, in the sense of characterizing the identity of this discipline, as well as criticizing this lack of connection, made explicitly by some authors.

Due to the nature of their content, descriptive and projective geometry had a connection with Mathematics developed in a perspective of construction recipes.

\section{The Culture of Mathematicians Guiding the Professional Practices of Teachers}

The articles did not reveal a connection between Technical Drawing and Mathematics. Though this connection could be expected considering one of the principles of the Regulation of 1951, which was the assumption that students should be considered the center of the Teaching and Learning process. To this end, one possibility would be to propose activities, tasks and lesson plans in which some connection based on the content itself occurred, to the extent in which, for example, Drawing in its technical dimension, according to some authors of the Journal, included geometric and projective drawing.

In relation to Mathematics, one can infer that appropriation, by the authors, of the prescriptions embodied in the legislation in effect, on the teaching and learning process of geometry, especially those referring to formal proofs, is strongly linked to the principles that guided the teaching practices of Mathematics teachers. We know that such practices are deeply characterized by the way in which mathematicians produce and validate knowledge in this area: rigor and formal proofs.

In sum, these authors agreed with the prescribed programs that deductive geometry should be worked on in class, respecting students' rhythm, needs and interests, as long as the teacher's practices do not diverge greatly from the maxim: formal proofs should be rigorous, taking into consideration that the proof is crucial in mathematical culture.

We observed that the History of Mathematics was

12 He was a teacher of Special Didactics of Technical Drawing at the National School of Philosophy of the University of Brazil. Author of the manual "How to teach technical drawing in the junior high program", published by MEC in the 1950s. 
considered only as a source of motivation for learning in order to promote attitudes and values in relation to this area of knowledge, but not as an appropriate means of teaching and learning concepts and procedures. These articles do not even present a selection of historical problems, practical or recreational, as a suggestion to be proposed and discussed in the Mathematics classes.

In these articles, and in others not cited here, there is a tension between adopting a discourse considered innovative, experimental and progressive and maintaining teaching practices that were developed by selective tradition, despite being considered inefficient.

We can see that the appropriation of innovative discourse for the teaching and learning process of Mathematics, the focus of which is essentially on the student, assumes the amalgam of it with teaching practices founded on how the knowledge produced by mathematicians is presented: with a focus on science.

Incorporating a discussion on the history of teaching Mathematics for training teachers in this discipline can contribute to understanding current contexts of teaching, as well as present elements for reflecting on the difficulties and problems faced in the everyday lives of teachers. The historical knowledge of teaching Mathematics can help in the elaboration of truly innovative and appropriate proposals for the present time.

\section{References}

Bandeira, J. S. (1957). O ensino de desenho geométrico. Revista Escola Secundária, 1, 74-78.

Baraldi, I. M. (2003). Retraços da Educação Matemática na Região de Bauru (SP): uma história em construção. Rio

\section{Claro: UNESP.}

Bicudo, J. C. (1942). O ensino secundário no Brasil e sua atual legislação: 1931 a 1941. São Paulo, [s.n.].

Bicudo, J. C. Lei Orgânica do Ensino Secundário. Decretolei n. 4.244, de 9 de abril de 1942. Manuais de Legislação Brasileira.

Carvalho, M.M.C. (2006). Livros e revistas para professores: Configuração material do impresso e circulação internacional de modelos pedagógicos. In: Pintassilgo, J.; Freitas, M.J.; Magarro, M.J. e Carvalho, M.M.C. (Eds), História da escola em Portugal e no Brasil. Circulação e apropriação de modelos culturais, pp. 141-173. Lisboa: Edições Colibri.

Certeau, M. D. (1994). A invenção do cotidiano. Petrópolis: Vozes.

Chartier, R. (1991). O mundo como representação. Estudos Avançados 11 (5), 173-191.

Fernandes, A. L. C. et al. (2006). Aspectos da imprensa periódica educacional em Lisboa e no Rio de Janeiro (1921 - 1963). Anais do VI Congresso Luso-Brasileiro de História da Educação, p 44-54.

Oliveira, M. C. A. (2015). Profissionalidade para o ensino de Geometria: Um estudo a partir da legislação. Revista de História da Educação Matemática.

Brasil. Portaria n ${ }^{\circ} 1045$ de 14 de dezembro de 1951. Publicado no Diário Oficial da União em 22 de fevereiro de 1952, p. 65.

Brasil. Ministério da Educação/CADES. Revista Escola Secundária (1957-1963), vol. 1 a 19. Disponível em: http:// repositorio.ufsc.br/xmlui/handle/123456789/157255

Santos, S. C. (1958). Introdução à didática especial do desenho. Revista Escola Secundária, 5, 91-97.

Valente W. R. (2008). Quem somos nós, professores de Matemática?. Cadernos Cedes, 28 (4), 11-23. 